\section{Issues raised by use of ethnic-group names in genome study}

I question the ethnic labels used by Stephan Schuster and colleagues in their paper 'Complete Khoisan and Bantu genomes from southern Africa' (Nature 463, 943-947; 2010) and in the public database where they deposited the sequences. The authors explain their choice of names in their Supplementary Information, but the terms Khoisan, Bantu and Bushman are perceived by those populations as outdated and even derogatory.

Khoisan derives from the Nama words for 'person' and 'foragers' and was coined by Leonard Schultze in 1928 as a collective term for the Khoi (later known as Khoe) pastoralist and the San hunter-gatherer groups. The term now persists only in a linguistic context, as in "Khoisan-speaking". The same applies to Bantu, which means 'people' but which acquired an offensive connotation during the apartheid regime in South Africa.

San communities (represented by the Working Group of Indigenous Minorities in Southern Africa and the South African San Institute) attending the 2003 African Human Genome Initiative conference declared a preference to be known either by their individual community names (!Xun or Khomani, for example) or collectively as San, rather than as Bushmen or Khoisan. If the San need to be grouped with the Khoe pastoralist groups, the term Khoe-San is preferred.

With southern Africa's history of racism and discrimination, people are very sensitive to the labels assigned to them. It is important that subjects participating in scientific research feel that the scientific community respects their sentiments.

Carina Schlebusch Department of Evolutionary Biology, Uppsala University, Norbyvägen 18D, 5236 Uppsala, Sweden e-mail:cschlebu@gmail.com

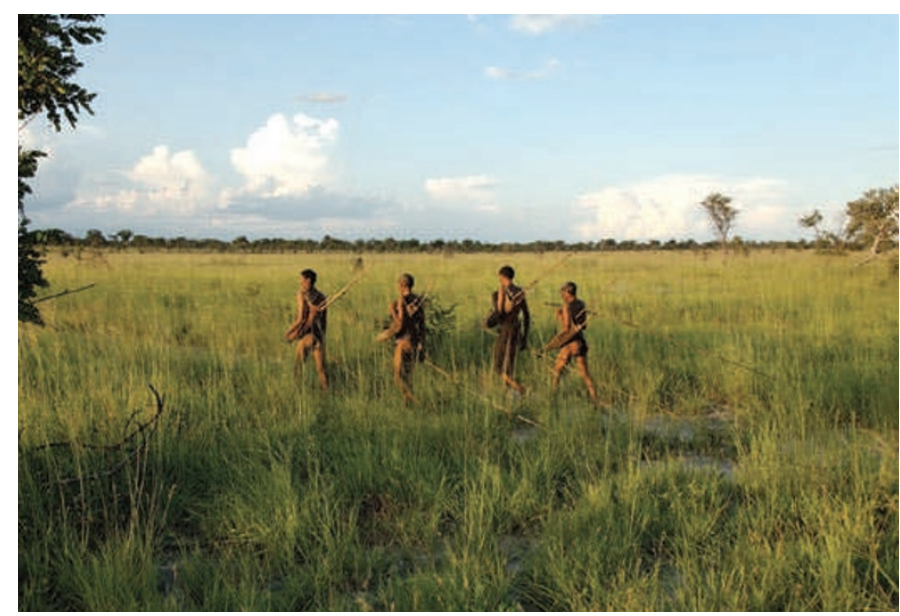

Schuster and colleagues reply: The naming conventions associated with indigenous hunter-gatherers of southern Africa are given in a historical, social and participant-driven context in the Supplementary Information to our paper (S. C. Schuster et al. Nature 463, 943-947; 2010). The four men we describe prefer to be addressed by their group names, namely Ju/'hoansi, !Kung and 'N/uhmte, but such individual-group naming does not allow for identification at the linguistic and genetic levels.

Historically, all group identifiers for indigenous hunter-gatherers of southern Africa have carried a negative connotation at some point, including those mentioned by Carina Schlebusch. In the post-apartheid era, a sense of common identity has emerged, based on shared experience and political awareness, leading to a recognition of the need for an overarching group name. However, the preferred identifier for these peoples continues to vary among groups, organizations and nations (see, for example, http://go.nature.com/hA6OgY).

Given the disparate nature of this nomenclature, we used the terms with which the participants themselves were most comfortable, out of respect for their right to ethnic selfidentification. The Namibian hunter-gatherer participants chose the name 'Bossiesman' (Afrikaans for 'bushmen') as their group identifier and expressed pride in the affiliation, stressing that the negative connotation is almost obsolete. Archbishop Tutu has declared himself proud to be Bantu and Bushmen since becoming aware of his Bushmen ancestry through our study. Pennsylvania State University, Center for Comparative Genomics and Bioinformatics, University Park, Pennsylvania 16802, USA e-mail: scs@bx.psu.edu

\section{Questions over the scientific basis of epigenome project}

We were astonished to see two sentences in your Editorial on the International Human Epigenome Consortium (Nature 463,587 ; 2010) that seem to disregard principles of gene regulation and of evolutionary and developmental biology that have been established during the past 50 years.

You say: "By 2004, largescale genome projects were already indicating that genome sequences, within and across species, were too similar to be able to explain the diversity of life. It was instead clear that epigenetics - those changes to gene expression caused by chemical modification of DNA and its associated proteins could explain much about how these similar genetic codes are expressed uniquely in different cells, in different environmental conditions and at different times."

With respect to 'epigenomics', we wish to stress that chromatin 'marks' and local chemical modifications of DNA, such as methylation, are the consequences of DNA-sequencespecific interactions of proteins (and RNA) that recruit modifying enzymes to specific targets. They are thus directly dependent on the genomic sequence. Such marks are the effects of sequencespecific regulatory interactions, not the causes of cell-typespecific gene expression.

Gene regulation explains in outline, and in many cases in detail, how similar genomes give rise to different organisms. Selfmaintaining loops of regulatory gene expression are switched on and off, producing the epigenetic effects that lie at the heart of development. Whereas the protein-coding toolkit is in part similar among species, the remainder of the genome, including almost all the regulatory sequence, is unique to each clade: therein lies the explanation for the diversity of animal life.

A letter signed by eight prominent scientists (not including us), and an associated petition signed by more than 50 , went into these matters in greater detail, and expressed serious reservations about the scientific basis of the epigenome project. A modified version of the letter appeared in Science (H. D. Madhani et al. Science 322, 43-44; 2008) - the complete letter can be found at http://madhanilab. ucsf.edu/epigenomics.

Mark Ptashne Sloan Kettering Institute, Memorial Sloan Kettering Cancer Center, 1275 York Avenue, New York, New York 10075, USA e-mail:m-ptashne@mskcc.org Oliver Hobert Columbia University Medical Center, Howard Hughes Medical Institute, Department of Biochemistry and Molecular Biophysics, New York, USA Eric Davidson Division of Biology 156-29, Caltech, California, USA tocorrespondence@nature.com. 